\title{
Corporate governance en de waardering van beursintroducties
}

Dr. L.R.T. van der Goot en Drs. P.G.J. Roosenboom

\section{Inleiding}

Dit artikel richt zich op de relatie tussen corporate governance en de waardering van beursintroducties, beschouwd vanuit de invalshoek van de externe aandeelhouders, die op het moment van beursgang hun aandelen verwerven. De verwachting is dat beleggers een grotere korting op de beursprijs eisen al naar gelang de gekozen corporate governance-karakteristieken minder goed in staat zijn om belangen- en informatieverschillen te mitigeren. Daarnaast wordt in dit artikel gepoogd het effect van de invoering van Bijlage $\mathrm{X}$ bij het Fondsenregelement te bestuderen. Bijlage X, van toepassing op beursintroducties sinds november 1989, staat maximaal twee beschermingsconstructies toe.

De beslissing om naar de beurs te gaan heeft vergaande gevolgen voor de zeggenschapsverhoudingen binnen de onderneming. Door de beursintroductie wordt de besloten kring van grootaandeelhouders verbreed met een grotere groep van externe, kleine aandeelhouders. Legde de ondernemingsleiding voorheen rekenschap af aan een beperkte kring van eigenaren, tot wie zij zelf meestal ook behoorde, in de toekomst zal ze zich moeten verantwoorden jegens een grote groep anonieme beleggers ${ }^{1}$.

De beursintroductie manifesteert daarmee een mogelijk belangenverschil tussen de externe aandeelhouders en de ondernemingsleiding. Zo zijn er ondernemingen die de voordelen van een beursgang wensen te incasseren, zonder echter zeggenschap aan buitenstaanders prijs te geven, aldus Moerland (1998, p.122). Bijvoorbeeld door een beursgang, waarbij de oorspronkelijke eigenaren meer dan $50 \%$ van de aandelen behouden. Of door middel van beschermingsmaatregelen die tot doel hebben vijandige overnames te verijdelen. Daarnaast heeft de ondernemingsleiding een informatievoorsprong op de externe aandeelhouders. Bestuurders verkeren in een prima positie om de vennootschap en haar vooruitzichten te doorgronden, terwijl beleggers nauwelijks bekend zijn met een nieuwkomer op de beurs. Deze combinatie van belangen- en informatieverschillen bemoeilijkt de waardering van beursintroducties en geeft aanleiding tot het vraagstuk van corporate governance.

Corporate governance kent vele facetten, getuige de veertig aanbevelingen van de CommissiePeters. De Commissie-Peters bezigt in haar rapport dan ook de volgende ruime definiëring (1997, p. 9): 'Governance gaat over besturen en beheersen, over verantwoordelijkheid en zeggenschap en over verantwoording en toezicht'. Moerland (1997, p. 661) hanteert de volgende omschrijving: 'Corporate governance is het geheel van structuren, regelingen en conventies dat bepalend is voor de wijze waarop en de effectiviteit waarmede een vennootschap - door middel van een door prikkels en tucht geregeerde interactie tussen stakeholders - wordt bestuurd en gecontroleerd'.

Door het ontwerpen van een optimale vennootschappelijke besturing, ofwel corporate governance, kan de ondernemingsleiding van de beursganger, althans in beginsel, de bovengenoemde belangen- en informatieverschillen verminderen. Hierbij kan worden gedacht aan beslissingen aangaande het aandelenbezit van bestuurders, het instellen van resultaatafhankelijke beloningssystemen en de grootte en samenstelling van de Raad van Commissarissen. Daarentegen kan de ondernemingsleiding corporate governance zodanig outilleren dat de belangen van de aandeelhouders ondergeschikt zijn en de informatie- en belangen-

Dr. L.R.T. van der Goot is verbonden aan de afdeling Accountancy en Informatiemanagement van de Universiteit van Amsterdam. Drs. P.G.J. Roosenboom is verbonden aan de afdeling Financiering van de Katholieke Universiteit Brabant. 
verschillen onverminderd voortduren. Bijvoorbeeld door het opwerpen van beschermingswallen of een partiële beursgang waarbij de bestuurders besluiten om de meerderheid van de zeggenschapsrechten te behouden. Op hun beurt zullen rationele beleggers de gekozen corporate governance-karakteristieken verdisconteren in de prijs die zij bereid zijn voor de aandelen te betalen.

De opbouw van het artikel is als volgt. Paragraaf 2 geeft een overzicht van de bestudeerde corporate governance-karakteristieken en hun verwachte relatie met ondernemingswaarde. In paragraaf 3 wordt de dataset van Nederlandse beursintroducties beschreven. Paragraaf 4 behandelt de methodologie van het onderzoek. De onderzoeksresultaten worden in paragraaf 5 weergegeven en besproken. De samenvatting en conclusies staan in paragraaf 6 .

\section{Corporate governance-karakteristieken}

\subsection{Aandelenbezit van bestuurders}

Het aandelenbezit van bestuurders biedt allereerst een mogelijkheid om het informatieverschil aan te pakken. Grinblatt en Hwang (1989) presenteren een model waarin het aandelenbezit van managers een geloofwaardig signaal afgeeft met betrekking tot hun private informatie over de kwaliteit van de betrokken onderneming. Door het aanhouden van een belang in de eigen onderneming verkrijgen risico-averse managers een lager nut dan zij hadden kunnen behalen door het aanhouden van een goed gespreide portefeuille van aandelen. Alleen de bestuurders van beursintroducties van hoge kwaliteit zullen welwillend zijn zich de voordelen van diversificatie te ontzeggen. Buitenstaanders worden hierdoor deelgenoot gemaakt in de private informatie over de kwaliteit van de beursintroductie. Gevolg is dat beleggers de waarde van de aandelen van die beursintroducties, waarin het bestuur een belangrijke aandeelhouder blijft, hoger zullen inschatten.

Aandelenbezit van bestuurders biedt evenzeer het hoofd aan het belangenverschil tussen managers en externe aandeelhouders. Het klassieke agencyprobleem, zoals beschreven in Jensen en Meckling (1976), speelt hier een rol. De aandeelhouders dragen beslissingsbevoegdheid over aan de ondernemingsleiding, wat een motivatie- en beoordelingsprobleem in het leven roept. Het aandelenbezit van het bestuur schakelt diens belang meer parallel met dat van de andere eigenaren, wat het motivatie- en beoordelingsprobleem vermindert. Een tweede reden om de prijs van de aandelen van die beursintroducties, waarin het management een kernaandeelhouder blijft, op te schroeven.

Een ander perspectief wordt geboden door Stulz (1988). Een geconcentreerd aandelenbezit door het management stelt het in staat een overheersende zeggenschap uit te oefenen en juist in tegenstrijd te handelen met de belangen van aandeelhouders. Hierbij kan worden gedacht aan een partiële beursgang, waarbij meer dan de helft van de stemrechten in handen blijft van bestuurders. Door haar dominerende aandelenbezit kan het bestuur zich ingraven en wordt de mogelijkheid tot ingrijpen door de overnamemarkt verkleind. De resultaten van De Jong en Moerland (1999) zijn consistent met de uitspraak dat in Nederland ter beurze genoteerde ondernemingen de concentratie van aandelenbezit beschouwen als een bescherming tegen overnamedreiging.

Het bovenstaande suggereert het bestaan van een niet-lineair verband tussen het aandelenbezit van bestuurders enerzijds en de ondernemingswaarde anderzijds: de ondernemingswaarde is alleen positief gerelateerd aan een laag of gemiddeld aandelenbezit van het management. Indien bestuurders besluiten als dominerende aandeelhouder aan te blijven, blijkend uit bijvoorbeeld een meerderheidsbelang door het management, kan nochtans sprake zijn van een negatieve samenhang met ondernemingswaarde.

\subsection{Personeelsopties}

Aanbeveling 24 van het rapport van de commissiePeters betreft personeelsoptieregelingen. Deze zouden moeten zien op een langetermijnbetrokkenheid bij de vennootschap. Opties moeten gerelateerd zijn aan de mate van succes van de inspanningen van de betrokkenen op de marktwaarde van de onderneming en moeten worden verantwoord in het jaarverslag. Het idee is dat door personeelsoptieregelingen de belangen van aandeelhouders saillant meer aandacht ontvangen, terwijl managers de vruchten van hun inzet kunnen plukken door de waardestijging van hun opties.

Het recent verschenen rapport 'Beursgang: striptease in een glazen huis' doet niettemin anders vermoeden, althans voorzover het gaat om verbetering van de bedrijfsvoering bij Nederlandse bedrijven die recentelijk naar de beurs zijn gegaan. Van der Goot en Heerschop (1999) vinden evenwel dat na de beursgang het aantal toegekende en uitgeoefende opties fors toeneemt. Enige tijd voor de beursgang worden door de bedrijven opties toegekend met een beduidend lagere uitoefenprijs dan de aan beleggers in rekening gebrachte emissiekoers. Wanneer de aandelenkoers van de onderneming zich in neerwaartse zin beweegt, worden in veel gevallen optieseries met een hoge uitoefen- 
prijs ingetrokken en ingeruild voor nieuwe opties met een lagere uitoefenprijs, hetgeen de verwachte positieve samenhang tussen personeelsopties en ondernemingswaarde ondermijnt.

\subsection{De grootte en samenstelling van de Raad van Commissarissen}

Een markant aspect van het Nederlandse corporate governance-systeem is de vooraanstaande en autonome positie van de Raad van Commissarissen. De leden van de Raad van Commissarissen zijn van rechtswege verplicht te waken over de belangen van de vennootschap als geheel en dienen derhalve ook met andere belangen dan die van de aandeelhouders rekening te houden. Echter, op voorhand is niet duidelijk wat die norm - 'het belang van de vennootschap' - precies inhoudt. Moerland (2000, p. 330) stelt 'wanneer men aan velen verantwoording verschuldigd is, is men het in feite aan niemand'. De grootte van de Raad van Commissarissen kan hierbij een rol spelen. Von Eije, De Witte en Van der Zwaan (2000) constateren dat de meeste ondernemingen, in aanloop naar een beursgang, de omvang van de Raad van Commissarissen uitbreiden. Een al te grote Raad van Commissarissen kan mogelijkerwijs uitnodigen tot coördinatie- en informatieproblemen, waardoor de effectiviteit van de toezichthoudende functie verder afneemt.

Met name in het geval van de structuurvennootschap is de invloed van de Raad van Commissarissen bijzonder groot. De Raad van Commissarissen heeft onder het structuurregime een aantal sleutelbevoegdheden: benoeming, schorsing en ontslag van bestuurders, vaststelling van de jaarrekening en goedkeuring van een aantal bestuursbesluiten (artikelen 134, 162 tot en met 164, boek 2 BW). Bovendien benoemt en schorst de Raad van Commissarissen haar leden zelf, het zogeheten coöptatie-systeem (artikelen 158 en 161, boek 2 BW). Hierdoor hebben aandeelhouders nauwelijks correctiemogelijkheden mocht de Raad van Commissarissen slecht functioneren, aldus Boot (1999, p. 540). Door sommigen wordt het structuurregime dan ook betiteld als een 'verkapte' beschermingsconstructie.

Een ander aandachtspunt betreft de onafhankelijkheid van de leden van de Raad van Commissarissen. De Commissie-Peters wenst in haar rapport onafhankelijkheid van commissarissen van belanghebbenden, en het voorkomen van de (schijn van) belangenverstrengeling. Onafhankelijkheid van belanghebbenden is noodzakelijk om te voorkomen dat de commissaris bij het uitoefenen van zijn toezichthoudende taak bepaalde belangen laat prevaleren ten koste van het belang van de vennootschap. Behoudens de wetsbepaling (artikel 160, boek 2 BW) dat werknemers geen commissaris kunnen zijn van diezelfde onderneming waarbij zij werkzaam zijn, bevat de wet echter geen andere bepalingen die bevriende kernaandeelhouders of banken van een commissariaat uitsluiten ${ }^{2}$. Alhoewel kernaandeelhouders en banken mogelijkerwijs een beter toezicht uitoefenen op de ondernemingsleiding, staat daar tegenover dat de belangen van deze partijen in sommige situaties kunnen conflicteren met die van de kleine aandeelhouders. Sommige banken hebben zich bijvoorbeeld openlijk uitgesproken tegen vijandige overnames (Het Financieele Dagblad, 14 december 1995). Cantrijn en Vente (1997) vinden dat slechts $20 \%$ van de ondervraagde institutionele beleggers bereid zijn om zich te moeien met de investeringsbeslissingen genomen door de ondernemingsleiding. Een waakzaam toezicht op de ondernemingsleiding lijkt ver te zoeken.

\subsection{Beschermingsconstructies en Bijlage X}

Beschermingsconstructies zijn een tweesnijdend zwaard. Ten eerste vormen ze een beproefd middel tegen vijandige overnames ('oorlogstijd'), ten tweede begrenzen beschermingswallen de zeggenschap van aandeelhouders ook wanneer een overnamedreiging afwezig is ('vredestijd'). De vraag is of beschermingsconstructies te allen tijde inefficiënt zijn. Beschermingsmaatregelen vergroten in 'oorlogstijd' de onderhandelingspositie van het bestuur vis-à-vis de agressor. Een voorbeeld is de uitgifte van preferente beschermingsaandelen aan bevriende partijen. De verwatering die ontstaat doordat de preferente aandelen slechts voor $25 \%$ van de nominale waarde hoeven te worden volgestort, biedt een effectieve, doch tijdelijke, bescherming. In de tussentijd kan de ondernemingsleiding komen tot een juiste afweging inzake de overname dan wel namens de aandeelhouders een hogere overnamepremie bedingen. Boot (1999, p. 540) acht om die reden tijdelijke beschermingsmuren acceptabel.

Permanente beschermingsconstructies, zoals certificering, prioriteitsaandelen en stemrechtbeperking zijn daarentegen ongewenst, daar ze de zeggenschap van aandeelhouders ook in 'vredestijd' beknotten. Certificering houdt in dat het zeggenschapsrecht en het dividendrecht van de aandelen gescheiden zijn. Het stemrecht verbonden aan de aandelen blijft berusten bij een administratiekantoor, terwijl de aandeelhouder zich tevreden moet stellen met alleen het dividendrecht. Aan prioriteitsaandelen zijn speciale zeggenschapsrechten verbonden, veelal inzake benoeming 
en ontslag van bestuurders en commissarissen en het goedkeuren van statutenwijzigingen. Prioriteitsaandelen kunnen zodanig worden ingevuld dat het structuurregime wordt geïmiteerd, waarbij moet worden aangetekend dat een gekwalificeerde meerderheid van gewone aandeelhouders de prioriteitsaandeelhouders kan dwingen met een andere bindende voordracht te komen. De wet (artikelen 118 en 228 boek 2 BW) opent tevens de mogelijkheid het stemrecht per aandeelhouder te beperken, ongeacht het aantal door de aandeelhouder gehouden dividendrechten. Uit onderzoek van Bosveld en Goedbloed (1996) en Kabir, Cantrijn en Jeunink (1997) blijkt dat de gemiddelde koersreactie bij aankondiging van een beschermingsconstructie negatief is, met name wanneer er sprake is van een overnamedreiging. Sinds 1960 is het aantal geslaagde bestuursonvriendelijke overnames op de vingers van één hand te tellen.

Niet verwonderlijk dat beschermingsconstructies reeds lange tijd omstreden zijn. Al in 1986 nam het beursbestuur voor het eerst openlijk scherp stelling tegen het opeenstapelen van beschermingsconstructies. Er diende paal en perk te worden gesteld aan het overmatige gebruik van beschermingsconstructies, omdat zo de rechten van aandeelhouders te veel werden beperkt ten gunste van de ondernemingsleiding. De Commissie Van der Grinten deelde in meerderheid de opvattingen van het beursbestuur echter niet en adviseerde de toenmalige status quo te handhaven. Het beursbestuur hield desalniettemin voet bij stuk en eiste een ingrijpend afbreken van beschermingswallen op straffe van verlies van notering aan de beurs. De paniekreactie die dit losmaakte bij de ter beurze genoteerde ondernemingen, leidde tot de oprichting van een opponent, de Vereniging van Effecten Uitgevende Ondernemingen (VEUO). Deze mengde zich met verve in het debat en slaagde erin zoveel pressie uit te oefenen dat in mei 1989 overeengekomen werd dat alle beursfondsen hun bestaande bescherming mochten handhaven.

Het beursbestuur werd echter wel gedeeltelijk tegemoetgekomen; het beperken van het aantal beschermingsconstructies in geval van beursintroducties. Deze moesten vanaf november 1989 aan strengere eisen voldoen. Een en ander werd vastgelegd in Bijlage $\mathrm{X}$ van het Fondsenregelement. Cumulatie van slechts twee van hierna te noemen beschermingsconstructies is sindsdien toegestaan (artikel 13 Bijlage X): preferente aandelen, certificering, stemrechtbeperking, prioriteitsaandelen en gemeenschappelijkbezitconstructies. Nietroyeerbare certificaten zijn niet langer toegestaan. Preferente aandelen tot $100 \%$ van het uitstaande aandelenkapitaal mogen slechts cumuleren met prioriteitsaandelen. Voor een meer uitgebreide bespreking van Bijlage X, zie Böhmer-Visser (1996, p. 111).

Met name permanente beschermingsconstructies blijken een waterdichte bescherming te bieden tegen vijandige overnames. Gevolg is dat de belangen van aandeelhouders worden geschaad en het aantal beschermingsconstructies een negatieve uitwerking heeft op de ondernemingswaarde. Bijlage X heeft het aantal beschermingsconstructies aan banden gelegd. Er mogen om die reden verschillen worden verwacht betreffende het aantal en de aard van beschermingsmaatregelen genomen door beursintroducties voor en na november 1989, het tijdstip waarop Bijlage X voor beursintroducties van kracht werd.

\section{Dataset}

Gedurende de jaren 1984-1999 hebben in totaal 146 ondernemingen een eerste notering verkregen aan de Amsterdamse Effectenbeurs. Daarvan zijn uiteindelijk 111 ondernemingen in dit onderzoek opgenomen (zie Tabel 1).

Tabel 1: Ondernemingen opgenomen in de steekproef

$\begin{array}{lcc}\begin{array}{l}\text { Aantal beursintroducties gedurende } \\ \text { de periode 1984-1999 }\end{array} & 146 \\ \text { Banken en andere financiële instellingen } & 14 & \\ \text { Split-ups } & 4 & \\ \text { Privatiseringen } & 4 & \\ \text { Ondernemingen met notering elders } & 4 & \\ \begin{array}{l}\text { Ondernemingen afkomstig van } \\ \text { de Incourante Markt }\end{array} & 9 & \\ & & 35- \\ \text { Resteert } & 111 \\ \text { waarvan } & \\ \text { Officiële Markt } & 60 \\ \text { Parallel Markt (1984-1992) } & 39 \\ \text { Nieuwe Markt (vanaf 1998) } & 12\end{array}$

Aandelenkoersen zijn afkomstig uit Datastream. De emissiekoersen, de boekhoudkundige gegevens en corporate governance-karakteristieken zijn afkomstig uit de emissieprospectussen van de betrokken ondernemingen. De computer hard- en software-industrie vormt met 20 ondernemingen het grootste contingent van de steekproef. Daarnaast zijn ondernemingen uit de zakelijke 
dienstverlening (16), de industrie (15), de groothandel (11) en de elektro-technische sector (10) sterk vertegenwoordigd.

Tabel 2 toont enkele statistische gegevens van de onderzochte ondernemingen. Gedurende de periode 1984-1999 zijn ondernemingen van velerlei omvang naar de beurs gegaan. De kleinste onderneming heeft op de eerste beursdag een marktwaarde van 25 miljoen gulden, de grootste een beurswaarde van 29,6 miljard gulden. De mediaan van de waarde van de bij de beursintroductie ter verkoop aangeboden aandelen bedraagt 48 miljoen gulden. Het initieel rendement op de eerste beursdag, gedefinieerd als het rendement behaald door beleggers die tegen de emissiekoers hebben ingeschreven op de aandelen, is 9,5 procent groot. De mediaan van de omzetgroei in het laatste boekjaar voor de beursintroductie is 24,2 procent met een gemiddelde-brutowinstmarge ter grootte van 11,2 procent van de omzet. De vermogensstructuur gemeten in boekwaarden bestaat voor 60,3 procent uit vreemd vermogen. De langetermijnschuld is beduidend kleiner, namelijk 12,3 procent. De mediaanleeftijd van nieuwkomers op de beurs is 15 jaar.

Figuren 1 en 2 laten de eigendomsverhoudingen voor en na de beursintroductie zien, opgedeeld naar de identiteit van de aandeelhouders. Het bestuur, gedefinieerd als leden van de Raad van Bestuur, leden van de Raad van Commissarissen en hun naaste familieleden, houdt voor en na de beursgang gemiddeld 44,4 procent, respectievelijk 29,8 procent van de aandelen. De ondernemingsleiding is en blijft daarmee de dominerende aan-

Tabel 2: Overzicht van beursintroductiekarakteristieken

De onderstaande tabel toont een overzicht van de beschrijvende karakteristieken voor 111 beursintroducties op de Amsterdamse Effectenbeurs van januari 1984 tot en met december 1999. Marktwaarde is bepaald door het aantal uitstaande aandelen na de beursintroductie te vermenigvuldigen met de slotkoers op de eerste handelsdag. Totale activa betreft de gerapporteerde totale activa in het boekjaar voorafgaande aan de beursintroductie. Verkoopopbrengst is gedefinieerd als het aantal aan beleggers verkochte aandelen vermenigvuldigd met de emissiekoers. Initieel rendement is berekend als het procentuele verschil tussen de slotkoers op de eerste handelsdag en de emissiekoers. De MB-ratio is berekend als het quotiënt van de marktwaarde op de eerste handelsdag en de boekwaarde van het eigen vermogen. De boekwaarde van het eigen vermogen is daarbij bepaald als de optelsom van het eigen vermogen gerapporteerd in het laatste boekjaar voor de beursintroductie en de verkoopopbrengst van de ten tijde van de beursintroductie nieuw uitgegeven aandelen. Indien tussen het sluiten van het laatste boekjaar een interimrapportage is verschenen, wordt de optelsom van het daarin vermelde eigen vermogen en de verkoopopbrengst van de nieuwe uitgegeven aandelen gebruikt. Omzetgroei betreft de groei in omzet gedurende het laatste boekjaar voorafgaande aan de beursgang. De brutowinstmarge betreft het resultaat voor interest, belasting en afschrijving uitgedrukt als een percentage van de omzet. De schuldratio is bepaald als vreemd vermogen gedeeld door balanstotaal in het boekjaar voorafgaand aan de beursgang. De langetermijnschuldratio is berekend als langetermijnschuld gedeeld door balanstotaal in het boekjaar voor de beursintroductie. De leeftijd betreft het aantal jaren dat de onderneming bestaat op het moment van haar beursintroductie. Alle geldbedragen zijn gecorrigeerd voor inflatie.

\begin{tabular}{|lrrrrc|}
\hline & Gemiddelde & Mediaan & Standaarddeviatie & Maximum & Minimum \\
\hline Marktwaarde (miljoenen NLG) & 940,475 & 136,61 & 3323,163 & 29646,951 & 25,421 \\
Totale activa (miljoenen NLG) & 358,344 & 77,346 & 811,859 & 4859,994 & 5,039 \\
Verkoopopbrengst (miljoenen NLG) & 196,969 & 47,809 & 468,211 & 3253,916 & 4,804 \\
Initieel rendement (\%) & 9,446 & 2,5 & 19,774 & 97,727 & $-31,237$ \\
MB-ratio & 6,194 & 3,627 & 6,956 & 415,32 & 0,57 \\
Omzetgroei (\%) & 39,248 & 24,212 & 50,812 & 308,031 & $-33,957$ \\
Brutowinstmarge (\%) & 11,235 & 12,386 & 25,252 & 61,176 & $-199,766$ \\
Schuldratio (\%) & 60,834 & 61,298 & 16,913 & 127,961 & 15,922 \\
Langetermijnschuldratio (\%) & 12,264 & 6,231 & 16,28 & 95,202 & 0 \\
Leeftijd (jaren) & 28,081 & 15 & 32,438 & 152 \\
\hline
\end{tabular}




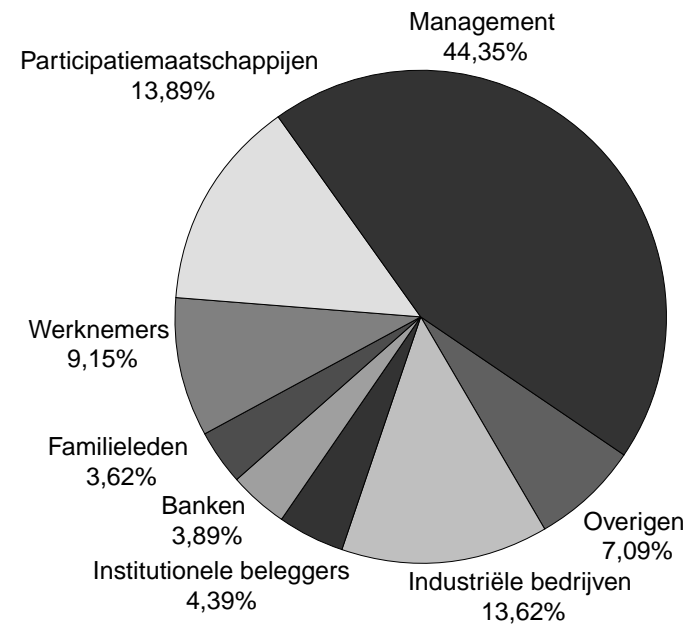

Figuur 1: Eigendomsstructuur voor de beursintroductie

deelhouder in de onderneming. Ter vergelijking, De Jong en Moerland (1999) rapporteren dat het gemiddelde aandelenbezit door bestuursleden in alle Nederlandse beursfondsen slechts 7 procent bedraagt. Bij de beursintroductie komt 33,3 procent van het geplaatste aandelenkapitaal in notering.

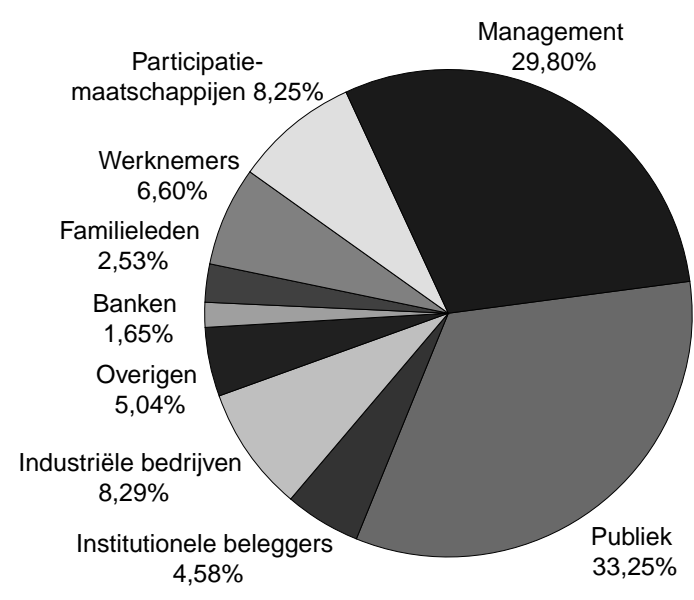

Figuur 2: Eigendomsstructuur na de beursintroductie

Tabel 3 laat zien dat maar liefst 82 procent van de beursgangers personeelsoptieregelingen hanteert of van plan is in de nabije toekomst personeelsopties uit te geven. De personeelsopties zijn in 44 gevallen voor alle werknemers bestemd en in 47 gevallen uitsluitend voor geselecteerde mede-

\section{Tabel 3: Overzicht van de bestudeerde corporate governance-karakteristieken}

De onderstaande tabel presenteert een overzicht van de bestudeerde corporate governance-karakteristieken van 111 beursintroducties op de Amsterdamse Effectenbeurs gedurende de periode januari 1984 tot en met december 1999. Aandelenbezit van bestuurders betreft het percentage aandelen dat na de beursgang in handen is van het bestuur, gedefinieerd als leden van de Raad van Bestuur, leden van de Raad van Commissarissen en hun naaste familieleden, uitgedrukt als percentage van na de beursintroductie uitstaande aandelen. Personeelsoptieregeling is het percentage beursintroducties dat een personeelsoptieregeling heeft ingevoerd of van plan is in de nabije toekomst personeelsopties toe te kennen. De omvang van de Raad van Commissarissen betreft het aantal leden. Structuurregime is het percentage beursintroducties dat opereert onder het wettelijk verplichte structuurregime. Onafhankelijke leden betreft het percentage leden van de Raad van Commissarissen die niet eerder werkzaam geweest zijn bij de onderneming, noch ruggespraak hoeven te houden met een bank of kernaandeelhouder. Kernaandeelhoudersleden is gedefinieerd als het percentage commissarissen dat banden heeft met een kernaandeelhouder, zoals bijvoorbeeld een participatiemaatschappij of een institutionele belegger. Bankrelaties is het percentage commissarissen dat een bank vertegenwoordigt. Het aantal beschermingsconstructies is het aantal beschermingsconstructies uit de lijst: certificering, prioriteitsaandelen, preferente aandelen, stemrechtbeperking en gemeenschappelijkbezitconstructies.

\begin{tabular}{|c|c|c|c|c|c|}
\hline & Gemiddelde & Mediaan & Standaarddeviatie & Maximum & Minimum \\
\hline Aandelenbezit van bestuurders (\%) & 29,803 & 24 & 28,745 & 89,997 & 0 \\
\hline Personeelsoptieregeling (\%) & 81,982 & 100 & 38,608 & 100 & 0 \\
\hline Omvang Raad van Commissarissen & 3,694 & 3 & 1,594 & 11 & 1 \\
\hline Structuurregime (\%) & 32,432 & 0 & 47,024 & 100 & 0 \\
\hline Onafhankelijke leden (\%) & 63,251 & 66,667 & 31,711 & 100 & 0 \\
\hline Kernaandeelhoudersleden (\%) & 21,295 & 0 & 30,471 & 100 & 0 \\
\hline Bankrelaties (\%) & 12,756 & 0 & 20,675 & 100 & 0 \\
\hline Aantal beschermingsconstructies & 1,306 & 1 & 0,724 & 3 & 0 \\
\hline
\end{tabular}


werkers en het topmanagement ('management in ruime zin'). Duffhues, Kabir en Mertens (1999) constateren dat 70 procent van de optieregelingen bij beursgenoteerde ondernemingen anno 1997 uitsluitend betrekking heeft op managers, zowel in ruime als in enge zin. De Raad van Commissarissen bestaat uit drie leden, gemeten aan de hand van de mediaan. De Jong en Moerland (1999) vinden voor een steekproef van alle Nederlandse beursfondsen van 1992 tot 1996 dat een gemiddelde Raad van Commissarissen uit vijf leden bestaat. Gemiddeld opereert 32,4 procent van de onderzochte beursintroducties onder het structuurregime. Tweederde deel van de Raad van Commissarissen bestaat uit onafhankelijke leden, gedefinieerd als die leden die niet eerder werkzaam zijn geweest bij de onderneming, noch een kernaandeelhouder of een bank vertegenwoordigen. Gemiddeld bestaat $12,8 \%$ en $21,3 \%$ van de commissarissen uit bankrelaties en leden die rug- gespraak houden met kernaandeelhouders, zoals participatiemaatschappijen en institutionele beleggers. Het aantal beschermingsconstructies per onderneming bedraagt één, gemeten aan de hand van de mediaan. De Jong en Moerland (1999) komen tot een mediaan van twee voor alle Nederlandse beursfondsen. Het verschil betreffende het aantal toegepaste beschermingsconstructies tussen beursintroducties en de totale populatie van beursfondsen is te herleiden tot de invoering van Bijlage X in november 1989 (zie Tabel 4).

Het mediaan aantal beschermingsconstructies bedraagt twee voor de groep van 53 beursintroducties voorafgaande aan Bijlage $X$, en één voor de groep van 58 beursgangers na november 1989. Het is opmerkelijk dat na de invoering van Bijlage $\mathrm{X}$ één beursintroductie, namelijk Apothekers Coöperatie OPG U.A., erin geslaagd is met drie beschermingsconstructies toegelaten te worden tot

Tabel 4: De invloed van de invoering van Bijlage $X$

Opgenomen in de analyse zijn 111 beursintroducties aan de Amsterdamse Effectenbeurs gedurende de periode januari 1984 tot en met december 1999. De steekproef wordt opgedeeld in twee groepen. Een eerste groep van 53 beursintroducties die voor de invoering van Bijlage X in november 1989 hebben plaatsgevonden en een tweede contingent van 58 beursintroducties die na november 1989 in notering zijn gekomen. De laatste kolom bestrijkt de totale periode van 1984-1999. Bijlage X van het Fondsenreglement voorziet in de cumulatie van slechts twee van hierna te noemen beschermingsconstructies: preferente aandelen, certificering, stemrechtbeperking, prioriteitsaandelen en gemeenschappelijkbezitconstructies (artikel 13 Bijlage X). Gezien stemrechtbeperking en gemeenschappelijkbezitconstructies zelden voorkomen zijn deze gecombineerd tot de categorie 'overige'. De vermelde getallen betreffen percentages van beursintroducties, behalve bij het gemiddelde en de mediaan waar het aantallen beschermingsconstructies betreft.

\begin{tabular}{|c|c|c|c|}
\hline & Voor Bijlage X & Na Bijlage X & 1984-1999 \\
\hline \multicolumn{4}{|c|}{ Aantal beschermingsconstructies } \\
\hline $0(\%)$ & 13,208 & 12,069 & 12,613 \\
\hline $1(\%)$ & 33,962 & 58,621 & 46,847 \\
\hline $2(\%)$ & 49,057 & 27,586 & 37,838 \\
\hline $3(\%)$ & 3,774 & 1,724 & 2,703 \\
\hline Gemiddelde & 1,434 & 1,19 & 1,306 \\
\hline Mediaan & 21 & 1 & \\
\hline \multicolumn{4}{|c|}{ Type beschermingsconstructie } \\
\hline Certificering (\%) & 43,396 & 15,517 & 28,823 \\
\hline Preferente aandelen $(\%)$ & 49,057 & 55,172 & 52,252 \\
\hline Prioriteitsaandelen $(\%)$ & 49,057 & 41,379 & 45,045 \\
\hline Overige $(\%)$ & 1,887 & 6,897 & 4,505 \\
\hline \multicolumn{4}{|c|}{ Cumulatie van beschermingsconstructies } \\
\hline $\begin{array}{l}\text { Certificering met } \\
\text { preferente aandelen }(\%)\end{array}$ & 13,208 & 8,621 & 10,811 \\
\hline $\begin{array}{l}\text { Certificering met } \\
\text { prioriteitsaandelen }(\%)\end{array}$ & 18,868 & 0 & 9,009 \\
\hline $\begin{array}{l}\text { Certificering met } \\
\text { overige }(\%)\end{array}$ & 1,887 & 3,448 & 2,703 \\
\hline $\begin{array}{l}\text { Preferente aandelen met } \\
\text { prioriteitsaandelen (\%) }\end{array}$ & 24,528 & 15,517 & 19,82 \\
\hline $\begin{array}{l}\text { Preferente aandelen } \\
\text { met overige }(\%)\end{array}$ & 0 & 3,448 & 1,802 \\
\hline $\begin{array}{l}\text { Prioriteitsaandelen } \\
\text { met overige }(\%)\end{array}$ & 1,887 & 1,724 & 1,802 \\
\hline
\end{tabular}


de Amsterdamse Effectenbeurs. Opvallend is ook dat de populariteit van certificering beduidend is afgenomen in de periode voor en na de invoering van Bijlage $X$, zonder dat hierbij sprake is van een toename in de andere permanente beschermingsconstructies. Ondanks dat Bijlage $\mathrm{X}$ royeerbare certificering niet aan banden legt, is deze beschermingsconstructie onder beursintroducties in onbruik geraakt. Kijkend naar de cumulatie tussen de verschillende beschermingsmaatregelen, valt op dat de combinatie preferente aandelen en prioriteitsaandelen na Bijlage $\mathrm{X}$ minder vaak voorkomt.

\section{Methodologie}

Om de samenhang tussen ondernemingswaarde en corporate governance-karakteristieken te bestuderen wordt gebruikgemaakt van regressieanalyse. Conform La Porta, Lopez-de-Silanes, Shleifer en Vishny (2000), wordt daarbij het quotiënt van de marktwaarde en de boekwaarde van het eigen vermogen (MB-ratio) als maatstaf voor ondernemingswaarde gebruikt. De marktwaarde van het eigen vermogen is bepaald door het aantal uitstaande aandelen na de beursintroductie te vermenigvuldigen met de slotkoers op de eerste handelsdag$^{3}$. De boekwaarde van het eigen vermogen is berekend als de optelsom van het eigen vermogen gerapporteerd in het laatste boekjaar voor de beursintroductie en de verkoopopbrengst van de ten tijde van de beursintroductie nieuw uitgegeven aandelen. Indien tijdens het sluiten van het laatste boekjaar een interimrapportage is verschenen, wordt de optelsom van het daarin vermelde eigen vermogen en de verkoopopbrengst van de nieuwe uitgegeven aandelen gehanteerd. Tabel 2 toont een gemiddelde MB-ratio van 6,2 en een mediaan MB-ratio ter grootte van 3,6.

Het doel van het onderzoek is het verklaren van verschillen in ondernemingswaarde aan de hand van corporate governance-karakteristieken. Niet alle variabelen zijn echter te plaatsen binnen het kader van corporate governance, maar dienen voor de volledigheid toch te worden opgenomen in het regressiemodel omdat deze invloed kunnen hebben op de ondernemingswaarde. Het regressiemodel luidt daarom als volgt:

$$
\begin{aligned}
& \text { MB-ratio }{ }_{\mathrm{i}}=\beta_{0}+\beta_{1} T A_{\mathrm{i}}+\beta_{2} L T S_{\mathrm{i}}+\beta_{3} B W M_{\mathrm{i}}+ \\
& +\beta_{4} O G_{\mathrm{i}}+\beta_{5} I C T_{\mathrm{i}}+\beta_{6} I N D_{\mathrm{i}}+\sum_{j=1}^{\mathrm{k}} \beta_{j} C G O V_{i j}+\varepsilon_{\mathrm{i}}
\end{aligned}
$$

waarbij voor onderneming $\mathrm{i}$ :

$\mathrm{TA}=$ Totale activa; gerapporteerde totale activa in het boekjaar voorafgaande aan de beursintroductie (inflatie gecorrigeerd).

$$
\begin{aligned}
& \text { LTS }=\text { Langetermijnschuldratio;langetermijn- } \\
& \text { schuld gedeeld door balanstotaal in } \\
& \text { het boekjaar voor de beursintroductie. } \\
& \mathrm{BWM}=\text { Brutowinstmarge; resultaat voor } \\
& \text { interest, belasting en afschrijvingen } \\
& \text { gedeeld door de omzet in het boekjaar } \\
& \text { voor de beursgang. } \\
& \mathrm{OG}=\text { Omzetgroe } \text {; groei in omzet gedurende } \\
& \text { het laatste boekjaar voorafgaande aan } \\
& \text { de beursgang. } \\
& \text { ICT = ICT-bedrijvendummy; waarde } 1 \text { als } \\
& \text { de onderneming actief is in de infor- } \\
& \text { matie communicatie technologie sector, } \\
& \text { anders } 0 \text {. } \\
& \text { IND = Industriële-bedrijvendummy; waarde } 1 \\
& \text { als het een industriële onderneming } \\
& \text { betreft, anders } 0 \text {. }
\end{aligned}
$$

Naast de zes genoemde controlevariabelen worden in de geschatte regressiemodellen één of meer corporate governance-karakteristieken opgenomen. Allereerst het percentage aandelen dat na de beursgang in handen is van het bestuur, gedefinieerd als leden van de Raad van Bestuur, leden van de Raad van Commissarissen en hun naaste familieleden, uitgedrukt als percentage van het na de beursintroductie uitstaande aandelen (Aandelenbezit van bestuurders). Om te onderzoeken of er sprake is van een niet-lineaire relatie tussen ondernemingswaarde en het aandelenbezit van bestuurders, wordt ook het aandelenbezit van bestuurders in het kwadraat (Aandelenbezit van bestuurders ${ }^{2}$ ) in het regressiemodel opgenomen. Indien de regressiecoëfficiënt van het gekwadrateerde aandelenbezit significant negatief is, biedt dit ondersteuning voor het bestaan van een dergelijke niet-lineaire relatie. Om de relatie tussen ondernemingswaarde en personeelsoptieregelingen te onderzoeken wordt gebruikgemaakt van een tweetal dummyvariabelen. Eén dummyvariabele (Personeelsopties; voor gehele personeel) neemt de waarde één aan indien de onderneming een personeelsoptieregeling heeft waarbij het voltallige personeel in aanmerking komt voor personeelsopties. De tweede dummyvariabele (Personeelsopties; alleen voor managers) neemt de waarde één aan indien de onderneming een personeelsoptieregeling heeft waarbij alleen topmanagers of geselecteerde werknemers ('managers in ruime zin') opties toegekend krijgen. De manier waarop de grootte en de samenstelling van 
de Raad van Commissarissen relateert aan ondernemingswaarde wordt met behulp van vijf variabelen onderzocht. Het aantal leden van de Raad van Commissarissen (Omvang Raad van Commissarissen) en een dummy (Structuurregime-

dummy) die de waarde één aanneemt indien de onderneming opereert onder het wettelijk verplichte structuurregime alsook het percentage commissarissen dat niet eerder werkzaam geweest is bij de onderneming, noch ruggespraak hoeft te houden met een bank of kernaandeelhouder (Onafhankelijke leden $R v C$ ), spelen hier een belangrijke rol. Twee dummyvariabelen (Kernaandeelhoudersdummy en Bankrelatiesdummy) nemen de waarde één aan indien ten minste één externe kernaandeelhouder, respectievelijk bankier in de Raad van Commissarissen vertegenwoordigd is. Om de invloed van beschermingsconstructies op ondernemingswaarde in kaart te brengen wordt gewerkt met het aantal beschermingsconstructies uit de lijst: certificering, preferente aandelen, prioriteitsaandelen, stemrechtbeperking en gemeenschappelijkbezitconstructies (Aantal beschermingsconstructies). Om de individuele relatie van certificering, preferente aandelen en prioriteitsaandelen met ondernemingswaarde te onderzoeken worden dummyvariabelen ingevoerd (Certificeringdummy, Preferente-aandelendummy en Prioriteitsaandelendummy) die de waarde één aannemen als de onderneming de desbetreffende beschermingsmaatregel toepast.

\section{Regressieresultaten}

\subsection{Aandelenbezit van bestuurders}

Zoals eerder verwoord, verkleint het aandelenbezit van bestuurders het informatie- en belangenverschil tussen bestuurders en aandeelhouders. De ondernemingsleiding is aandeelhouder in de eigen onderneming en vereenzelvigt zichzelf meer met de belangen van de andere eigenaren. De onderzoeksresultaten van kolom (1) van Tabel 5 onderbouwen deze uitspraak. De regressiecoëfficiënt van de variabele Aandelenbezit van bestuurders is significant positief. Het niet-lineaire verband tussen het aandelenbezit van bestuurders en ondernemingswaarde komt minder goed uit de verf. De regressiecoëfficiënt van het gekwadrateerde aandelenbezit (Aandelenbezit van bestuur$d e r s^{2}$ ) is weliswaar negatief, maar niet statistisch significant. Naarmate het aandelenbezit van bestuurders groter wordt, wordt de positieve uitwerking op ondernemingswaarde kennelijk niet al te veel overschaduwd door de negatieve effecten, zoals het verkleinen van de mogelijkheid tot ingrijpen door de overnamemarkt.

\subsection{Personeelsopties}

Een andere manier om de belangen van de ondernemingsleiding en aandeelhouders parallel te doen lopen, is het gebruikmaken van personeelsopties. In kolom (2) van Tabel 5 wordt een onderscheid gemaakt tussen twee categorieën, namelijk personeelsopties voor het voltallige personeel en personeelsopties die alleen worden toegekend aan topmanagers en geselecteerde werknemers ('managers in ruime zin'). Alleen die optieregelingen waarbij alle werknemers voor opties in aanmerking komen (Personeelsopties; voor gehele personeel) leiden tot een significant hogere waarde van de onderneming. Er wordt geen significante samenhang gevonden tussen ondernemingswaarde en opties, als alleen het 'management in ruime zin' met opties wordt beloond (Personeelsopties; alleen voor managers). Deze uitkomsten zijn consistent met Von Eije, De Witte en Van der Zwaan (2000). Zij komen tot de conclusie dat het verstrekken van opties aan een kleine groep van managers weinig effect heeft op de efficiëntie van de bedrijfsvoering.

\subsection{De grootte en samenstelling van de Raad van Commissarissen}

Kolom (3) van Tabel 5 toont de resultaten met betrekking tot de grootte en samenstelling van de Raad van Commissarissen. De regressiecoëfficiënt van de variabele Omvang Raad van Commissarissen is significant negatief. Naarmate de Raad van Commissarissen groter wordt, zullen informatie- en coördinatieproblemen hun intrede doen, waardoor de toezichthoudende functie afneemt. Hoewel het structuurregime aandeelhouders van een aantal elementaire zeggenschapsrechten berooft, heeft het structuurregime (Structuurregimedummy) geen significante verlaging van de ondernemingswaarde tot gevolg. De significante positieve relatie tussen de variabele Onafhankelijke leden $R v C$ en ondernemingswaarde bevestigt het vermoeden dat onafhankelijkheid door beleggers op prijs wordt gesteld. Echter, gegeven de significant positieve regressiecoëfficiënt van de variabele Kernaandeelhoudersdummy, oefenen ook kernaandeelhouders, zoals participatiemaatschappijen en andere institutionele beleggers, een waakzaam toezicht uit op de ondernemingsleiding. Bankiers die in de Raad van Commissarissen zijn vertegenwoordigd (Bankrelatiesdummy), genieten daarentegen minder vertrouwen van beleggers en hebben geen duidelijke invloed op de ondernemingswaarde. Dergelijke leden van de Raad van Commissarissen dienen eerder het belang van 
Tabel 5: Regressieresultaten

De analyse betreft 111 beursintroducties gedurende de periode 1984-1999. De t-waarde van de regressiecoëfficiënten zijn tussen haakjes vermeld en heteroskedasticiteit-consistent (gebaseerd op White standaardfouten). Het symbool '***' duidt op een significantie van $1 \%$ betrouwbaarheid, ' $* *$ ' duidt op een significantieniveau van $5 \%$ en het symbool '*' duidt op een significantieniveau van $10 \% . \mathrm{R}^{2}$ is aangepast voor het aantal parameters. De zinvolheid van de geschatte vergelijking is getoetst door middel van een F-toets. In alle regressies fungeert de MB-ratio als afhankelijke variabele. Kolom (6) toont de resultaten voor de periode voor de invoering van Bijlage X in november 1989 (53 waarnemingen), kolom (7) voor de periode erna (58 waarnemingen).

\begin{tabular}{|c|c|c|c|c|c|c|c|c|}
\hline & (l) & (2) & (3) & (4) & (5) & $\begin{array}{l}\text { Voor Bijlage X } \\
\text { (6) }\end{array}$ & $\begin{array}{l}\text { Na Bijlage X } \\
\text { (7) }\end{array}$ & (8) \\
\hline Intercept & $1.222,(3.38)^{* * *}$ & $1.251,(4.47)^{* * *}$ & $1.098,(3.36)^{* * *}$ & $1.927,(7.21)^{* * *}$ & $1.842,(7.08)^{* * *}$ & $1.529,(3.67)^{* * *}$ & $2.101,(6.30)^{* * *}$ & $0.804,(2.08)^{* *}$ \\
\hline Totale activa & $-0.099,(-1.83)^{*}$ & $-0.131,(-2.75)^{* * *}$ & $-0.046,(-0.74)$ & $-0.147,(-3.21)^{* * *}$ & $-0.137,(-3.11)^{* * *}$ & $-0.088,(-1.22)$ & $-0.171,(-2.88)^{* * *}$ & $-0.030,(-0.498)$ \\
\hline $\begin{array}{l}\text { Langetermijn- } \\
\text { schuldratio }\end{array}$ & $0.341,(0.58)$ & $0.378,(0.61)$ & $-0.057,(-0.09)$ & $0.327,(0.58)$ & $0.394,(0.800)$ & $-0.480,(-0.58)$ & $0.642,(0.76)$ & $0.259,(0.40)$ \\
\hline Brutowinstmarge & $1.018,(2.95)^{* * *}$ & $0.953,(2.87)^{* * *}$ & $0.885,(2.26)^{* *}$ & $0.973,(3.05)^{* * * *}$ & $1.058,(3.65)^{* * *}$ & $1.558,(1.25)$ & $0.976,(2.06)^{* *}$ & $0.859,(2.469)^{* *}$ \\
\hline Omzetgroei & $0.791,(4.35)^{* * *}$ & $0.732,(4.53)^{* * *}$ & $0.822,(4.640)^{* * *}$ & $0.744,(4.40)^{* * *}$ & $0.780,(4.89)^{* * *}$ & $0.531,(1.71)^{*}$ & $0.700,(3.51)^{* * *}$ & $0.726,(4.33)^{* * *}$ \\
\hline $\begin{array}{l}\text { ICT-bedrijven- } \\
\text { dummy }\end{array}$ & $0.381,(2.49)^{* * *}$ & $0.424,(2.901)^{* * * *}$ & $0.345,(2.06)^{* *}$ & $0.322,(2.09)^{* *}$ & $0.222,(1.429)$ & $0.631,(2.49)^{* *}$ & $0.073,(0.33)$ & $0.305,(1.91)^{*}$ \\
\hline $\begin{array}{l}\text { Industriële } \\
\text { bedrijvendummy }\end{array}$ & $-0.489,(-2.89)^{* * *}$ & $-0.455,(-3.03)^{* * *}$ & $-0.540,(-3.36)^{* * *}$ & $-0.578,(-3.74)^{* * *}$ & $-0.512,(-3.49)^{* * *}$ & $-0.469,(-2.48)^{* *}$ & $-0.474,(-1.96)^{*}$ & $-0.452,(-2.90)^{* * *}$ \\
\hline $\begin{array}{l}\text { Aandelenbezit } \\
\text { van bestuurders }\end{array}$ & $1.437,(1.83)^{* *}$ & & & & & & & $0.856,(1.09)$ \\
\hline $\begin{array}{l}\text { Aandelenbezit } \\
\text { van bestuurders }{ }^{2}\end{array}$ & $-1.479,(-1.61)$ & & & & & & & $-0.600,(-0.68)$ \\
\hline $\begin{array}{l}\text { Personeelsopties; } \\
\text { voor gehele personeel }\end{array}$ & & $0.502,(3.05)^{* * *}$ & & & & & & $0.349,(2.09)^{* *}$ \\
\hline $\begin{array}{l}\text { Personeelsopties; } \\
\text { alleen voor managers }\end{array}$ & & $0.218,(1.315)$ & & & & & & $0.028,(0.171)$ \\
\hline Omvang Raad van & & & & & & & & \\
\hline Commissarissen & & & $-0.088,(-1.98)^{* *}$ & & & & & $-0.056,(-1.14)$ \\
\hline Structuurregimedummy & & & $-0.215,(-1.16)$ & & & & & $-0.017,(-0.08)$ \\
\hline Onafhankelijke leden Rv & & & $0.569,(2.07)^{* *}$ & & & & & $0.563,(2.018)^{* *}$ \\
\hline Kernaandeelhouders- & & & & & & & & \\
\hline ledendummy & & & $0.349,(2.09)^{* *}$ & & & & & $0.354,(2.12)^{* *}$ \\
\hline Bankrelatiesdummy & & & $0.091,(0.63)$ & & & & & $0.087,(0.63)$ \\
\hline $\begin{array}{l}\text { Aantal beschermings- } \\
\text { constructies }\end{array}$ & & & & $-0.185,(-2.10)^{* *}$ & & $-0.179 \cdot(-1.78)^{*}$ & $-0.085,(-0.71)$ & $-0.170,(-1.79)^{*}$ \\
\hline Certificeringdummy & & & & & $-0.554,(-3.55)^{* * *}$ & & & \\
\hline Preferente-aandelendum & nmy & & & & $0.034,(0.28)$ & & & \\
\hline Prioriteitsaandelendumm & & & & & $-0.184,(-1.59)$ & & & \\
\hline $\mathrm{R}^{2}$, F-toets & $0.529,16.49^{* * *}$ & $0.555,18.12^{* * *}$ & $0.540,12.74 * * *$ & $0.541,19.49^{* * *}$ & $0.615,17.99^{* * *}$ & $0.576,11.08^{* * *}$ & $0.492,8.91^{* * *}$ & $0.577,10.39^{* * *}$ \\
\hline
\end{tabular}


de bank dan dat van de aandeelhouders. Dit neemt overigens niet weg dat de deskundigheid van een bankier een reden kan zijn om hem of haar een commissariaat aan te bieden, zeker in de aanloop naar de beursgang.

\subsection{Beschermingsconstructies en Bijlage X}

Kolom (4) van Tabel 5 laat de invloed van het aantal beschermingsconstructies op de ondernemingswaarde zien. De regressiecoëfficiënt van de variabele Aantal beschermingsconstructies is significant negatief. Naarmate het aantal beschermingsconstructies toeneemt, neemt de ondernemingswaarde af. Kolom (5) beschouwt de drie meest voorkomende beschermingsconstructies afzonderlijk (Certificeringdummy, Preferente-aandelendummy en Prioriteitsaandelendummy).

Alleen de regressiecoëfficiënt voor certificering is statistisch significant en negatief. De tijdelijke bescherming genoten door de mogelijkheid preferente aandelen uit te geven, beïnvloedt de ondernemingswaarde niet significant. Dit komt overeen met de bevindingen van Kabir, Cantrijn en Jeunink (1997) die vinden dat de machtiging tot het uitgeven van preferente aandelen niet leidt tot een significante koersreactie. Kolom (6) toont de regressieresultaten voor de groep van 53 beursintroducties die in notering zijn gekomen voor de invoering van Bijlage $X$ in november 1989. Het aantal beschermingsconstructies toont een significant negatief verband met ondernemingswaarde. Kolom (7) laat de resultaten zien voor de groep van 58 nieuwkomers op de beurs na de invoering van Bijlage X. Het aantal beschermingsconstructies is in deze periode niet langer significant gerelateerd aan ondernemingswaarde.

\subsection{Totaalbeeld}

Tot slot is een regressiemodel geschat waarin alle bestudeerde corporate governance-karakteristieken zijn opgenomen. De resultaten staan in kolom (8) van Tabel 5. Alleen de regressiecoëfficiënten voor de variabelen Aandelenbezit van bestuurders en Omvang Raad van Commissarissen verliezen significantie. Alle overige bevindingen blijven kwalitatief ongewijzigd.

\section{Samenvatting en conclusie}

Gedurende de jaren 1984-1999 hebben 146 ondernemingen een eerste notering verkregen aan de Amsterdamse Effectenbeurs. Daarvan zijn er uiteindelijk 111 in dit onderzoek geanalyseerd. In geval van een beursgang is er in meer of mindere mate sprake van informatie- en belangenverschillen tussen ondernemingsleiding en de externe aandeelhouders, die op het moment van de beursintroductie hun aandelen verwerven. Deze informatie- en belangenverschillen kunnen beteugeld worden door het ontwerpen van corporate governance. Beleggers zullen op hun beurt de door de ondernemingsleiding gekozen corporate governance-karakteristieken verdisconteren in de prijs die ze bereid zijn voor de aandelen te betalen.

De gepresenteerde resultaten geven aan dat corporate governance haar sporen nalaat op de ondernemingswaarde. Het aandelenbezit door bestuurders, een personeelsoptieregeling voor alle werknemers, een Raad van Commissarissen bestaande uit onafhankelijke leden en toezicht door kernaandeelhouders zijn positief gerelateerd aan de waarde van nieuwe beursfondsen. De ondernemingswaarde wordt negatief beïnvloed door de aanwezigheid van beschermingsconstructies, met name certificering. Bijlage $\mathrm{X}$ van het Fondsenregelement, die de cumulatie van beschermingsmaatregelen beperkt tot twee, speelt hierbij een belangrijke rol. Beursintroducties voor de invoering van Bijlage $X$ in november 1989 passen vaker certificering toe en kiezen vaker voor een opeenstapeling van preferente aandelen en prioriteitsaandelen dan beursintroducties na november 1989. Bovendien relateren beschermingsconstructies alleen negatief aan ondernemingswaarde voor de groep van 53 ondernemingen die voor de invoering van Bijlage $X$ in notering kwamen. Wanneer een regressiemodel wordt geschat waarin alle corporate governance-karakteristieken worden opgenomen, blijven de meeste bevindingen intact.

\section{LITERAT U UR}

Beursgang: striptease in een glazen huis, (1999), Heidrick \& Struggles en Faculteit Bedrijfskunde Rijksuniversiteit Groningen, rapport.

Bijvoet, C.J. en P.W. Moerland, (1996), Strategische overwegingen voor een beursintroductie van een onderneming, in: Op weg naar de beurs, Kluwer Bedrijfswetenschappen, Amsterdam, pp. 11-25.

Böhmer-Visser, S., (1996), Organisatie en regels van de Amsterdamse Effectenbeurs, in: Op weg naar de beurs, Kluwer Bedrijfswetenschappen, Amsterdam, pp. 95-116.

Boot, A.W.A., (1999), Corporate governance: hoe nu verder?, Maandblad voor Accountancy en Bedriffseconomie, 73, pp. 533-544.

Bosveld, R. en A.M. Goedbloed, (1996), Effecten van beschermingsconstructies op aandeelkoersen, Maandblad voor Accountancy en Bedrijfseconomie, 70, pp. 261-270.

Cantrijn, D. en J. Vente, (1997), Institutionele beleg- 
gers en corporate governance in Nederland, Bedrijfskunde, 69, pp. 51-60.

Commissie Corporate Governance, (1997), Corporate governance in Nederland: de veertig aanbevelingen, Deventer: Kluwer.

Duffhues, P.J.W., R. Kabir en G.M.H. Mertens, (1999), Personeelsoptieregelingen in Nederland: theorie en praktijk, CentER Applied Research, Katholieke Universiteit Brabant, rapport.

Eije, J.H. von, M.C. de Witte en A.H. van der Zwaan, (2000), De effecten van een beursgang op de organisatie van een onderneming, Tijdschrift voor Bedrijfsadministratie, 104, pp. 334-340.

Goot, L.R.T. van der en J. Heerschop, (1999), De uitoefening van personeelsopties: een onderzoek naar personeelsopties bij nieuw genoteerde Nederlandse ondernemingen, Economisch en Sociaal Tijdschrift, 53, pp. 545-566.

Grinblatt, M. en C.Y. Hwang, (1989), Signalling and the Pricing of New Issues, Journal of Finance 44, pp. 393-420.

Jensen, M.C. en W.H. Meckling, (1976), Theory of the Firm: Managerial Behavior, Agency Costs and Ownership Structure, Journal of Financial Economics 3, pp. 305-360.

Jong, A. de en P.W. Moerland, (1999), Beheersingsmechanismen in Nederland: substituut of complement?, Maandblad voor Accountancy en Bedrijfseconomie, 73, pp. 499-512.

Kabir, R., D. Cantrijn en A. Jeunink, (1997), Takeover Defenses, Ownership Structure and Stock Returns in the Netherlands: an Empirical Analysis, Strategic Management Journal 18, pp. 97-109.

La Porta, R., F. Lopez-de-Silanes, A. Shleifer en R.W. Vishny, (2000), Investor Protection and Corporate Valuation, Harvard University, working paper.

Manen, J.A. van en R.B.H. Hooghiemstra, (1999), Normen voor commissarissen: een verwachtingskloof?, Maandblad voor Accountancy en Bedrijfseconomie, 73, pp. 513-524.

Moerland, P.W., (1997), Corporate governance: schakering, reikwijdte en definiëring, Maandblad voor Accountancy en Bedrijfseconomie, 71, pp. 657-665.

Moerland, P.W., (1998), Corporate governance en de vermogenskosten van de onderneming, Maandblad voor Accountancy en Bedriffseconomie, 72, pp. 116-124.

Moerland, P.W., (2000), Onafhankelijkheid van ondernemingstoezicht, Maandblad voor Accountancy en Bedriffseconomie, 74, pp. 324-332.

Stulz, R.M., (1988), Managerial Control of Voting Rights: Financing Policies and the Market for Corporate Control, Journal of Financial Economics 20 , pp. 25-54.

\section{NOTEN}

1 Vergelijk Bijvoet en Moerland (1996, p. 11).

2 Vergelijk Van Manen en Hooghiemstra (1999, p. 515).

3 Een inherente beperking is dat de MB-ratio een momentopname betreft. Vooral het feit dat de slotkoers op de eerste handelsdag wordt gebruikt impliceert dat het initieel rendement hierin verdisconteerd zit. 